\begin{tabular}{lll}
\hline Bentham open & The Open Sports Sciences Journal \\
\hline CrossMark & Content list available at: www.benthamopen.com/TOSSJ/ & DOI: $10.2174 / 1875399 X 01609010094$ \\
\hline
\end{tabular}

\title{
Playoffs or Just League: A Debate in Brazilian Football
}

\author{
Thadeu Gasparetto ${ }^{1}$ and Angel Barajas ${ }^{1,2, *}$ \\ ${ }^{I}$ Faculty of Business Administration and Tourism, University of Vigo, Campus Universitario As Lagoas s/n, 32004, \\ Ourense, Galicia, Spain \\ ${ }^{2}$ National Research University Higher School of Economics, Lebedeva st., 27, 614070, Perm, Russian Federation
}

Received: July 16, 2015

Revised: August 18, 2015

Accepted: September 07, 2015

\begin{abstract}
After several consecutive seasons in the league, the Campeonato Brasileiro may return to the playoffs format. The Brazilian Football Confederation (CBF) and some Brazilian clubs commented that this format will provide higher competitive balance and increase the interest of Brazilian football fans. Therefore, the objective of this paper is to assess the competitiveness and the interest of Brazilian fans in the last twenty-four seasons: Playoffs (1991-2002) and League (2003-2014). The competitiveness is evaluated by Herfindahl Index of Competitive Balance (HICB) and C4 Index of Competitive Balance and the interest measured by the average attendance to the stadiums. The results show that Brazilian League has become more balanced since 2003 season and football fans are more interested in the tournament with league format. The main conclusion is that the change to the playoffs would not improve the competitiveness and the interest of fans. Moreover some problems of the Brazilian football market are commented and some solutions proposed to improve it.
\end{abstract}

Keywords: Average Attendance, Brazilian League, C4 Index of Competitive Balance, Competition Format, Competitive Balance, Football, Herfindahl Index of Competitive Balance.

\section{INTRODUCTION}

Brazil is one of the leading countries in football. Its history was built by great players as Pelé, Garrincha, Romario, Ronaldo, Ronaldinho and many others who contributed to win five times the FIFA World Cup. Apart from its legendary players, Brazil is a 'factory' of players. According the Global Transfers Market Report 2015 [1], 1,493 Brazilian players were transferred in 2014. This figure represents the $11.41 \%$ over the total amount of players transferred, being the nationality with a higher trade.

Brazilians refer to their nation as the 'country of football'. In his book, Milan [2] made a relationship between football and Brazilian culture highlighting fun, improvisation and creativity. Guterman [3] described football in Brazil as a social phenomenon identifying its population and explaining the history of the country.

Currently, Brazil is in a better international situation than some decades ago. It is one of the emergent economies ranking sixth according Gross Domestic Product (GDP) in the world in 2011. However, still a huge inequality exists in the country. Its ranking according GDP per capita at Purchasing Power Parity (PPP) decreases until the $75^{\text {th }}[4]$ and $79^{\text {th }}$ on Human Development Index (HDI) [5]. These two last data reflect the economic and social problems that exist in Brazil.

The Brazilian football market has always been different from the more traditional football leagues in Europe. There, the season starts in January and ends in December. Simultaneously, as Gasparetto, Fernández-Jardón and Barajas [6] explain, other tournaments exist: the Campeonatos Estaduais. In addition, the Campeonato Brasileiro also differs with most European leagues: the tournament was decided in Playoffs between 1959 and 2002. During this period, the

\footnotetext{
* Address correspondence to this author at the Faculty of Business Administration and Tourism, University of Vigo, Spain; Tel: +34988368713 ; Fax:+34988368923; E-mail: abarajas@uvigo.es
} 
championships were organized in all kinds of format: regionalized, divided into groups, a league with 96 clubs took place in 1979, and even a tournament where a team that had played the second division finished in second place in Serie $\mathrm{A}$ in the same season (in 2000). However, after 44 seasons, the main football tournament in Brazil adopted a league format (double Round Robin) in 2003.

About to complete the thirteenth consecutive season under the league format in 2015, the Campeonato Brasileiro may change again its format. The Chairman of the Confederação Brasileira de Futebol (CBF) has announced the possibility of modifying the competitive format of the League if the football teams in Brazil agree on it and, according with the opinion of clubs' managers, most of them would be interested in returning to Playoffs.

As the Campeonato Brasileiro was played in this format along much of its history, it is culturally understandable that managers believe that the return to the previous model could be interesting. But, would be really a good alternative back from League to Playoffs format? The objective of this research is to compare the Campeonato Brasileiro before and after the 2003 season, analyzing the arguments of the CBF and the clubs to justify the change of the main Brazilian tournament again and conclude whether it is worthwhile the return to the previous format.

\section{THEORETICAL BACKGROUND}

Although there are different models for organizing a football tournament, the common format for most of the major leagues is a tournament where teams play twice (home and away) against each one of the opponents. This happens in England [7], Germany [8], Italy [9], Spain, France and many other countries [10, 11]. However, countries like Argentina, Austria, Belgium, Chile, Denmark, Major League Soccer US and some others organize their competitions with different formats. The studies by Griggs and Rosa [10] and Goossens and Spieksma [11] reflect that diversity of models.

Rottemberg [12] noted the importance of the uncertainty of sporting results in the interest of the fans. Forrest and Simmons [13] corroborated that idea and added that high levels of competitiveness mean better levels of television audiences, average attendance and general interest. Under these assumptions, many studies have been devoted to analyze the competitive balance in sports leagues. Among the most varied measures of competitiveness, the most popular are: Herfindal-Hirschman Index (HHI) [14], C5 Index of Competitive Balance (C5ICB) [14], Gini coefficient [15], Competitive Balance Ratio (CBR) [16] and National Measure of Seasonal Imbalance (NAMSI) [17]. In addition to the studies cited above, many others have used these measures and developed others, even assessing competitiveness in medium and short term.

Although prominent on the pitch, Brazilian football is not noted in the literature, Leoncini and Silva [18], in an exploratory study, investigated the football market in Brazil and its economic and structural characteristics. Reis, Remedios, Telles and DaCosta [19] have shown the financial progress of Brazilian clubs between 2003 and 2012 seasons, although Gasparetto [20] has shown that football teams have a much lower financial flow than leading companies in other markets. Nevertheless, the Brazilian League (Campeonato Brasileiro) has been studied by Araujo Jr., Shikida Monastery [21], Madalozzo and Villar [22] Barros, Assaf and Sat-Earp [23] and Barros, Wanke and Figueiredo [24]. This fact shows a recent increase in academic interest in the subject. However, to date only the study of Drummond, Araujo Jr. and Shikida [25] has analyzed the competitive balance in the Campeonato Brasileiro.

\section{MATERIALS AND METHODS}

This research was conducted through a natural experiment, using what happened in Brazilian football. As it has been explained in the introduction, the Campeonato Brasileiro started in 1959. From then until 2002 the champion of the league was decided through playoffs. However, during that time, different models of competition were applied changing almost every season. All the information about the whole period of competition can be find at the site Futpédia (http://futpedia.globo.com/). The Campeonato Brasileiro changed its competitive model to league in 2003. Through a critical analysis, that change is empirically investigated, assessing the competitive balance and the interest of the fans before and after the 2003 season. Accordingly, the Campeonato Brasileiro has been divided into two periods of twelve seasons: 1991-2002 and 2003-2014. The motivation for carrying this study arises from the possibility of changing the format of the competition again. Therefore, it seeks to assess the two main reasons sustained by the CBF and some clubs:

J1: tournaments organized with Playoffs format is more balanced than the League.

J2: fans prefer a tournament with Playoffs. 
Due to the fact that the number of teams participating in the competition has varied in the seasons analyzed in the period studied, the competitive balance has been analyzed through the Herfindahl Index of Competitive Balance (HICB) developed by Michie and Oughton [14]. This formula is an adaptation of the Herfindahl-Hirschman Index (HHI), but it eliminates the errors caused by the different number of teams.

$$
H I C B=\left(\frac{\sum_{i=1}^{N} S_{i}^{2}}{1 / N}\right) \times 100
$$

where:

$s_{i}=$ share of team $i$ in the total points in the league.

$N=$ number of teams in the league.

Moreover, the C5 Index of Competitive Balance developed by Michie and Oughton [14] has been commonly used to analyze the competitiveness in football. This Index reflect the concentration of points obtained by the 5 first teams in the ranking in relation with the total amount of points. This is a measure of the competitive balance in the league. However, in this study, the C4 Index of Competitive Balance (C4ICB) has been used. It represents the group of Brazilian teams qualified to the Copa Libertadores. This index has been adjusted by Drummond, Araújo Jr. y Shikida [25]. The index is estimated with the following formula:

$$
C 4 I C B=\left(\frac{C 4 \text { ratio }}{4 / N}\right) \times 100
$$

where:

$$
\text { C4 ratio }=\frac{\text { Total points won by the top four clubs }}{\text { Total number of points won by all clubs }}
$$

$N=$ number of teams in the league.

The value 100 represents the maximum balance in each season in both indexes. If the value increases the competitive balance decreases. The estimations has been done using the points obtained at the end of the season. In the seasons with playoff format, the results of the playoff matches final has been considered to estimate the final classification. The data has been collected in the site The Rec. Sport. Soccer Statistics Foundation (http://www. rsssfbrasil.com).

Table 1. Seasonal HICB, C4ICB and average attendance of Campeonato Brasileiro: 1991-2014.

\begin{tabular}{|c|c|c|c|}
\hline Season & HICB & C4ICB & Average Attendance \\
\hline 1991 & 104.38 & 128.15 & 13,760 \\
\hline 1992 & 103.68 & 127.68 & 10,914 \\
\hline 1993 & 121.45 & 193.70 & 10,222 \\
\hline 1994 & 107.58 & 144.19 & 10,332 \\
\hline 1995 & 108.93 & 139.66 & 10,913 \\
\hline 1996 & 106.95 & 132.17 & 10,497 \\
\hline 1997 & 112.69 & 164.05 & 13,487 \\
\hline 1998 & 111.41 & 155.33 & 17,018 \\
\hline 1999 & 110.64 & 150.79 & 11,546 \\
\hline 2000 & 108.87 & 149.13 & 11,401 \\
\hline 2001 & 107.74 & 151.77 & 12,866 \\
\hline 2002 & 105.86 & 137.27 & 10,468 \\
\hline 2003 & 104.15 & 134.08 & 7,556 \\
\hline 2004 & 104.25 & 135.12 & 13,600 \\
\hline 2005 & 125.10 & 129.78 & 12,300 \\
\hline 2006 & 105.21 & 133.26 & 17,471 \\
\hline 2007 & 104.79 & 124.28 & 16,992 \\
\hline 2008 & 104.39 & 133.62 & 17,807 \\
\hline 2009 & 103.23 & 124.75 & 14,839 \\
\hline 2010 & 105.34 & 132.97 & \\
\hline
\end{tabular}


(Table $\square$ ) contd.....

\begin{tabular}{|c|c|c|c|}
\hline (Table $\square$ ) contd..... & C4ICB & Average Attendance \\
\hline Season & HICB & 127.53 & 14,976 \\
\hline 2011 & 104.11 & 138.16 & 13,013 \\
\hline 2012 & 105.94 & 129.88 & 14,951 \\
\hline 2013 & 105.07 & 137.40 & 16,555 \\
\hline 2014 & 106.18 & & \\
\hline
\end{tabular}

First, the evolution of competitiveness and the differences between the two groups is observed graphically. Subsequently, the competitive balance in the Campeonato Brasileiro under the league and playoff format is compared statistically. For that, the Mann-Whitney U test for independent samples is used to check the difference between the averages of the two groups. P-value lower than 0.05 has been considered significant.

Then, the interest of fans on the competition is investigated. The average attendance of the tournaments is used as a measure of interest, following the work by Szymanski [26]. First, the average attendance of the two periods and the difference between the first and last year played under league and playoff is observed, highlighting the increase or decrease of interest within each period. This data has been collected in the site Futdados (http://futdados.com/). The average attendance was calculated by dividing the total attendance by the number of matches. The occupancy rate is not appropriate to Brazilian football due to the fact that football clubs in Brazil usually play as home team in different stadiums. Table 1 shows the values of HICB, C4ICB and average attendance used in this paper.

\section{RESULTS AND DISCUSSION}

\section{Competitive Balance in Campeonato Brasileiro}

Figs. (1 and 2) show the values of competitive balance in the Campeonato Brasileiro during seasons between 1991 and 2014. The competitive behavior in the twenty-four years investigated is presented. It is observed that the competitive balance in the Campeonato Brasileiro has improved after the change in the model of competition in the 2003 season. The changes in competitiveness in the twelve seasons with league format are small, except in the year 2005. This exception will be explained later. In Figs. (3 and 4), the competitiveness between the two formats -league and playoffs- are compared.

A significant imbalance happens in two of the seasons investigated. In 1993, the CBF eliminated the second national division, including in the Campeonato Brasileiro two teams relegated from 1992 season and twelve clubs who had played in the lower division in the previous year. This resulted in a tournament with 32 teams, which created a great technical imbalance between clubs. In 2005, the Campeonato Brasileiro was marked by the manipulation of results. A referee went to jail and eleven matches refereed by him had to be played again. Thus, it is assumed that the imbalance resulted from the change in the classification after the new matches. However, this imbalance in 2005 season was observed only through HHICB. It was not found in C4ICB.

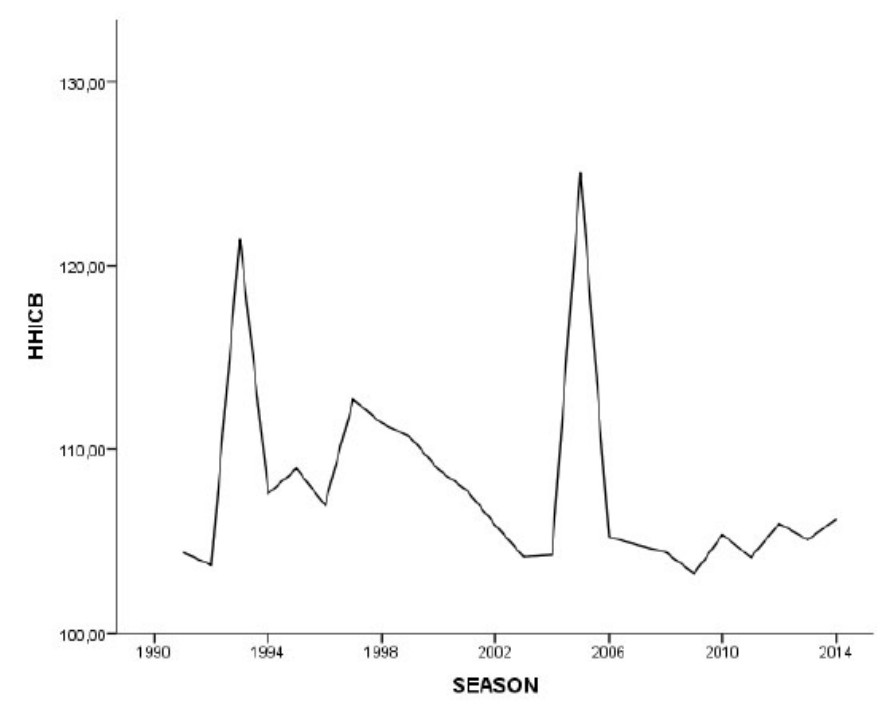

Fig. (1). Herfindhal Index of Competitive Balance in Campeonato Brasileiro: 1991-2014. 


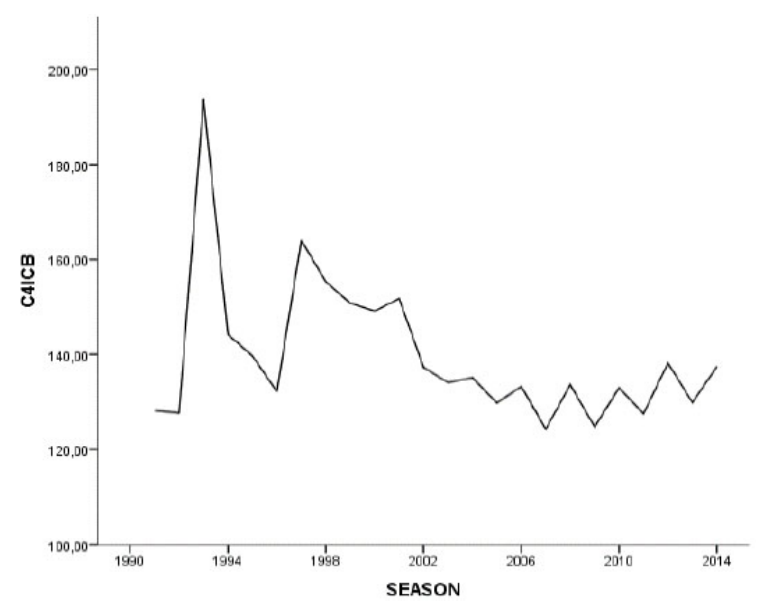

Fig. (2). C4 Index of Competitive Balance in Campeonato Brasileiro: 1991-2014.

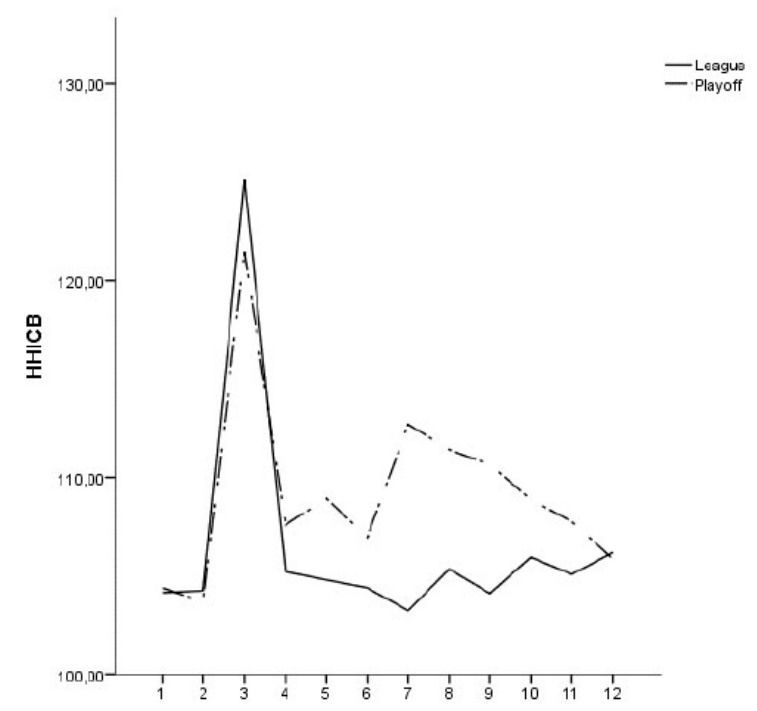

Fig. (3). Differences in HICB in Campeonato Brasileiro: Playoffs vs. League

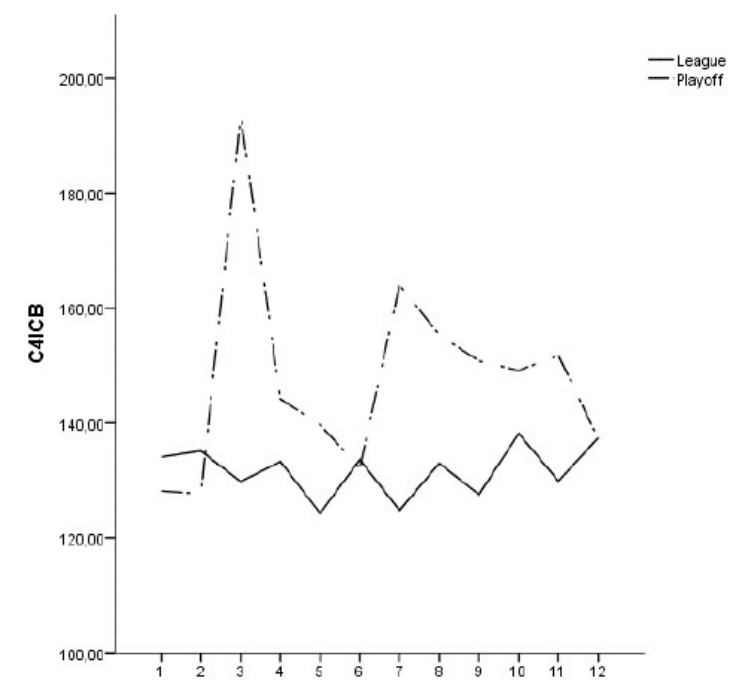

Fig. (4). Differences in C4ICB in Campeonato Brasileiro: Playoffs vs. League 
Although the graphs have shown an improvement in competitiveness after the change in 2003, Mann-Whitney U test for independent samples has been carried out to check if there was significant difference between groups. The results are presented in Tables $\mathbf{2}$ and $\mathbf{3}$.

Table 2. Mann-whitney U test in HICB of Campeonato Brasileiro: Playoffs vs. liga.

\begin{tabular}{|c|c|c|c|}
\hline Null Hypothesis & Test & Sig. & Decision \\
\hline Distribution in Playoffs is the same than in League & Mann-Whitney U Test for independent samples & $0.017 *$ & Reject the null hypothesis \\
\hline
\end{tabular}

$(* p<0,05)$

Table 3. Mann-Whitney U test in C4ICB of Campeonato Brasileiro: Playoffs vs. Liga.

\begin{tabular}{|c|c|c|c|}
\hline Null Hypothesis & Test & Sig. & Decision \\
\hline Distribution in Playoffs is the same than in League & Mann-Whitney U Test for independent samples &, $008 *$ & Reject the null hypothesis \\
\hline
\end{tabular}

$(* p<0,05)$

The test confirms the statistical difference between the groups. Thus, there is an evidence that league is more balanced than playoffs. The finding corroborates the results of Drummond, Araujo Jr. and Shikida [25]. The authors evaluated the historical competitiveness of the Campeonato Brasileiro between 1971 and 2009 seasons using four indices. They emphasized the increased competitive balance after the change of the league format. Thus, they concluded that altering the format was beneficial for the main Brazilian football tournament since that change improved its competitiveness. Therefore, we can say that back to the format of playoffs arguing an increase in competitiveness would not be justified in the Campeonato Brasileiro.

Goossens, Beliën and Spieskma [27] have researched the possible change in competitive model in the Belgian League. They showed that the format suggested by the Royal Belgian Football Association would improve the competitiveness in its league. However, they stressed that the increase in the total number of matches could jeopardize the performance of the teams qualified for European Championships.

Lee and Fort [28] completed a longitudinal investigation on English football. They observed changes in competitiveness after historical events, such as pre and post wars. Besides all the changes in the competitive balance in older seasons, they showed in their study a significant increase in imbalance since 1997 season. According to these authors, this fact came as a consequence of the financial inequality produced by the participating clubs in UEFA Champions League.

\section{Which Kind of Competition do the Fans Prefer?}

In a second stage, the preference of fans, measured by average attendance to the stadia, in each format of competition is evaluated. Figs. (5 and 6) show the evolution of the average attendance in the Campeonato Brasileiro and the differences between the periods under the system of league and playoffs.

It is noted that the interest in the competition increased after the change of the system in season 2003. However, the 2004 season had the lowest average attendance. This could be explained for the many criticisms that the league model suffered by the press and fans during that season. Criticisms emerged as the champion of the Brazilian League in 2003 also won its Estadual and the Copa do Brasil. Thus, the press and the fans imagined that imbalance in Brazilian football would start. This reality did not happen: the 2003 season was the only one that a team won these three types of tournaments in Brazil. A slight trend of growth in average attendance in Campeonato Brasileiro is appreciated. The average attendance in the period under league system was $14 \%$ higher than in the seasons under playoffs. In addition, comparing the championships 1991 and 2002 (the twelve seasons with playoffs format), the attendance decreased $6.50 \%$. However, in the league period, average attendance grown 58.15\% from 2003 season to 2014. It is worth mentioning that the average attendance in Campeonato Brasileiro never has been high. The peak in history was 22,953 persons in season 1983. Therefore, there is a remarkable change from 12,866 spectators in season 2002 (last in playoffs) to 16,555 in season 2014 with league system. 


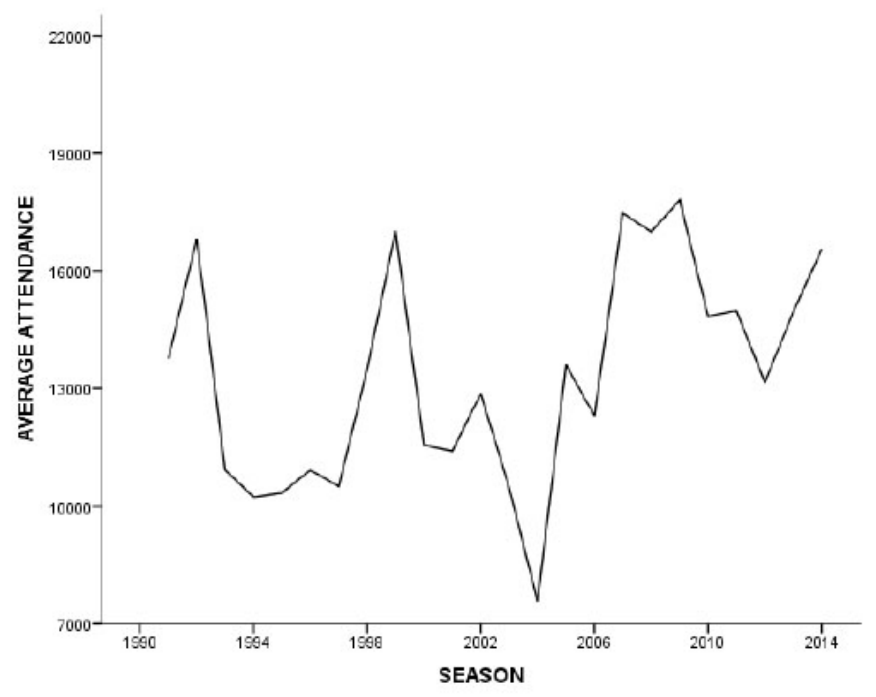

Fig. (5). Evolution of average attendance in Campeonato Brasileiro: 1991-2014.

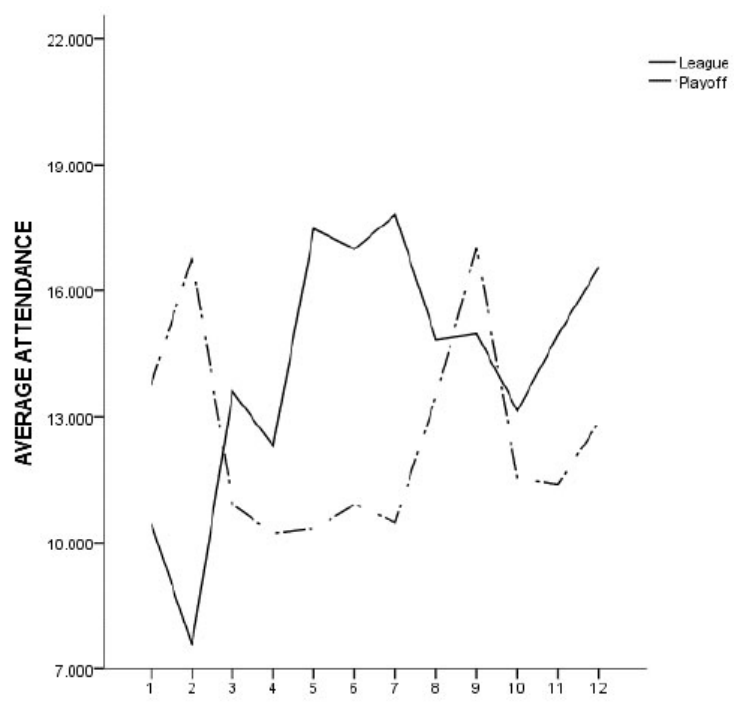

Fig. (6). Comparison of average attendance in Campeonato Brasileiro: Playoffs vs. League.

\section{Considerations on Brazilian Football}

Violence is one of the main problems of Brazilian football. According to a newspaper [29], 234 deaths were recorded in Brazilian football between 1988 and 2013. Although the amount has decreased in 2014 [30], it is still unacceptable. However, Murad [31] states that the problem is not specifically for football, but is a social reflection of Brazil, which also has unacceptable numbers of casualties in automobile accidents, drugs and other deaths. However, until now, not much was done in Brazil to restrain violence in football, and this is the main justification of fans for not attending the matches at the stadium [32].

It should be stressed that Brazilian clubs will have a unique opportunity to attract fans in the coming seasons. In 2014, Brazil hosted the FIFA World Cup, which has meant the construction of new stadiums and the reform of many others. Feddersen, Maenning and Borcherding [33] have demonstrated what they call "novelty effect" in the German Bundesliga after the construction of new stadiums. Similarly, it is easy to expect that Brazilian teams could increase average attendance in their competitions if they know how to use the full potential of the new sports venues.

The number of members of the Brazilian clubs is still low when considering the Brazilian population and estimate the size of the fans of each team. However, it is worth noting the evolution that has occurred in the last four years. Nevertheless, teams will have to improve a lot the club-fan relationship to increase revenue. Solberg [34] highlights the 
price bundling strategy to increase revenue and Howard and Crompton [35] the creation of various models of seasontickets to attract different groups of fans. Specifically in the case of Brazil, Madalozzo and Villar [22] have highlighted the need of selling season-tickets for the clubs, something that is unusual in Brazilian football. Sordi and Bello [36] corroborate this idea, adding as a strategy to include other products in these ticket packages.

In line with the results obtained in this study, Drummond, Araujo Jr. and Shikida [25] have shown the improvement in the competitive balance in the Campeonato Brasileiro after changing the format of the competition in 2003. Levy [37] and Gasparetto and Barajas [38] have highlighted more balanced the Brazilian football when compared to European leagues. However, a worrying situation for many fans has appeared in recent years: the financial imbalance that a wrong distribution of television revenues can generate in Brazilian football. As noted in the report by Itaú BBA [39], television resources are the main source of income for clubs in Brazil. They say that analyzing the accumulated earnings at the end of five seasons the difference between the club with higher revenues and the tenth one will go up to something close to an increase of 1 million euros per month. Finally, the above mentioned report points out that to keep the competitive balance would be necessarily a more equal distribution of television revenues. Thus, based on evidence of Lee and Fort [28], who found that the financial imbalance decreases the sporting competition, greater equity in the distribution of television revenues to maintain and improve the existing competitive balance in the Campeonato Brasileiro is necessary.

From the results presented, an interesting fact should be mentioned. In the league format, a season in particular has stood out for being the most competitive and had the best average attendance: 2009 season. In their study, Ribeiro and Urrutia [40] proposed a program that optimized the match schedule in the Campeonato Brasileiro. They created a model based on the 2005 and 2006 seasons. The CBF used their model for the first time in the tournament in 2009. As a result, a more balanced league was observed than in previous seasons. These authors also report that they used the same program to generate the 2010 calendar but they had some limitations because it was the year of FIFA World Cup and a higher concentration of teams from the same State negatively influenced that season. However, although competitiveness has declined from one year to the other, the tournament also was decided on the final day, fact that did not occur in previous seasons. Thus, it is evident that there are other ways to increase the competitiveness of a football tournament and make it more attractive that just changing to playoffs.

It is imperative to clarify that the critics are not against the format of playoffs in sports championships. The success of sports in the United States, as well as the case of the UEFA Champions League and the FIFA World Cup, confirm the feasibility and importance of this system of competition. However, specifically analyzing the Campeonato Brasileiro de Futebol, the playoffs model is not expected to improve the current league system.

\section{CONCLUSION}

This article brings to the conclusion that changing the Campeonato Brasileiro model of competition to playoffs does not guarantee an improvement. The results deny the justification of the Confederação Brasileira de Futebol and some clubs for the change, as a greater balance and an increase in average attendance is evidenced after setting the league format (Double Round Robin) in the 2003 season. Finally, it is stated that the progress of the market for Brazilian football would improve focusing in other aspects like the reduction of violence, optimize the sales of tickets for the matches, improving the relationship between club-fan and decrease the financial difference in the distributions of television revenue. These alternatives would help more the development of the Campeonato Brasileiro than going back to a format that does not guarantee increased competitive balance and attraction to the stadiums.

\section{CONFLICT OF INTEREST}

The authors confirm that this article content has no conflict of interest.

\section{ACKNOWLEDGEMENTS}

The authors thank the referees for their anonymous work to improve the quality of this paper. We also want to thank the guest editors Prof. Carvalho and Prof. Leonor Guerrero Gallardo for their initiative to promote this special issue and their work to make it possible.

This study comprises research findings from the Basic Research Program at the National Research University Higher School of Economics (HSE) and supported within the framework of a subsidy granted to the HSE by the Government of the Russian Federation for the implementation of the Global Competitiveness Program. 


\section{REFERENCES}

[1] Global Transfers Market Report. 2015. Available from: http:/www.fifatms.com/Global/Testimonials/Gtm/Preview-GTM15.pdf

[2] Milan B. O país do futebol. $1^{\text {st }}$ ed. Rio de Janeiro: Record 1998.

[3] Guterman M. O futebol explica o Brasil - Uma história da maior expressão popular do país 1 São Paulo. $1^{\text {st }}$ ed. Brasil: Editora Contexto 2009. Available from: http://editoracontexto.com.br/futebol-explica-o-brasil-o.html

[4] International Monetary Fund. World Economic Outlook Database. 2014. Available from: http://www.imf.org/external/pubs/ft/weo/2014/01/ weodata/index.aspx

[5] Human Development Report 2014 Sustaining human progress: reducing vulnerabilities and building resilience, UN Plaza, New York, NY 10017, USA 2014. Available from: http://hdr.undp.org/sites/default/files/hdr14-summary-en.pdf

[6] Gasparetto T, Fernández-Jardón C, Barajas A. Brand teams and distribution of wealth in Brazilian State Championships. Working paper BRP 30/MAN/2014, Higher School of Economics, National Research University 2014. [http://dx.doi.org/10.2139/ssrn.2542117]

[7] Kendall G. English football fixtures over holiday periods. J Oper Res Soc 2008; 59: 743-55. [http://dx.doi.org/10.1057/palgrave.jors.2602382]

[8] Bartsch T, Drexl A, Kroger S. Scheduling the professional soccer leagues of Austria and Germany. Comput Oper Res 2006; $33(7)$ : $1907-37$. [http://dx.doi.org/10.1016/j.cor.2004.09.037]

[9] Della Croce F, Olivieri D. Scheduling the Italian Football League: and ILP-based approach. Comput Oper Res 2006; 33(7): 1963-74. [http://dx.doi.org/10.1016/j.cor.2004.09.025]

[10] Griggs TS, Rosa A. A tour of European soccer schedules, or testing the popularity of GK $2 \mathrm{n}$. Bull Inst Comb Appl 1996; 18 : 65-8.

[11] Goossens DR, Spieksma FC. Soccer schedules in Europe: an overview. J Sched 2012; 15: 641-51. [http://dx.doi.org/10.1007/s10951-011-0238-9]

[12] Rottemberg S. The baseball players' labor market. J Polit Econ 1956; 64(3): 242-58. [http://dx.doi.org/10.1086/257790]

[13] Forrest D, Simmons R. Outcome uncertainty and attendance demand in sport: the case of english soccer. Statistician 2002; 51(2): 229-41. [http://dx.doi.org/10.1111/1467-9884.00314]

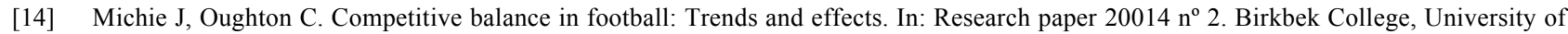
London: Football Governance Research Center 2004.

[15] Schimidt MB. Competition in Major League Baseball: The impact of expansion. Appl Econ Lett 2001; 8(1): 21-6. [http://dx.doi.org/10.1080/135048501750041231]

[16] Humphreys B. Alternative measures of competitive balance. J Sports Econ 2002; 3(2): 133-48. [http://dx.doi.org/10.1177/152700250200300203]

[17] Goossens J. Competitive balance in European football: comparison by adapting measures: national measure of seasonal imbalance and top 3. Riv Dir Econ Sport 2006; 2: 77-122.

[18] Leoncini MP, Silva MT. Entendendo o futebol como um negócio: Um estudo exploratório. Gest Prod 2005; 12(1): 11-23. [http://dx.doi.org/10.1590/S0104-530X2005000100003]

[19] Reis RM, Remédios JL, Telles SC, DaCosta LP. The football business in Brazil: Connections between the economy, market and media. Motriz Revista de Educação Física 2014; 20(2): 120-30. [http://dx.doi.org/10.1590/S1980-65742014000200001 ]

[20] Gasparetto TM. O futebol como negócio: Uma comparação financeira com outros segmentos. Rev Bras Ciênc Esporte 2013; 35(4): 825-45. [http://dx.doi.org/10.1590/S0101-32892013000400003]

[21] Araújo AF Jr, Shikida C, Monasterio LM. Uma análise econométrica do futebol brasileiro. Anal Econ 2005; 23(44): 217-40.

[22] Madalozzo R, Villar RB. Brazilian Football: What brings fans to the game. J Sports Econ 2009; 10(6): 639-50. [http://dx.doi.org/10.1177/1527002509335572]

[23] Barros CP, Assaf A, Sá-Earp F. Brazilian football league technical efficiency: a simar and wilson approach. J Sports Econ 2010; 11(6): 641-51. [http://dx.doi.org/10.1177/1527002509357530]

[24] Barros CP, Wanke P, Figueiredo C. The Brazilian Soccer Championship: an efficiency analysis. Appl Econ 2015; 47(9): 906-15. [http://dx.doi.org/10.1080/00036846.2014.982857]

[25] Drummond L, Araújo AF Jr, Shikida CD. Campeonato brasileiro de futebol e balanço competitivo: uma análise do período 1971-2009. Rev Bras Fisioter 2010; 3(2): 73-87.

[26] Szymanski S. Income inequality, competitive balance and the attractiveness of teams sports: some evidence and natural experiment from english soccer. Econ J 2001; 111: F69-84. [http://dx.doi.org/10.1111/1468-0297.00599] 
[27] Goossens DR, Beliën J, Spieksma FC. Comparing league formats with respect to match importance in Belgium football. Ann Oper Res 2010; 194: 223-40. [http://dx.doi.org/10.1007/s10479-010-0764-4]

[28] Lee YH, Fort R. Competitive balance: times series lessons from english premier league. Working paper $\mathrm{n}^{0} 2011-02$, Research Institute for Market Economy: Sogang University 2011.

[29] Lancenet! Violência entre torcidas já matou 234 pessoas no Brasil, sendo 30 este ano. Available from: http://www.lancenet.com.br/ minuto/Violenciatorcidas_organizadas_0_10444495544.html

[30] Castro CO. Brasil é o recordista de mortes por causa do futebol. Available from: http://oglobo.globo.com/esportes/ brasil-orecordista-demortes-por-causa-do-futebol-14923352

[31] Murad M. Práticas de violência e mortes de torcedores no futebol brasileiro. Rev USP 2013; 99: 139-52. [http://dx.doi.org/10.11606/issn.2316-9036.v0i99p139-152]

[32] Sport TV. Pesquisa: violência é a principal causa que afasta torcedores dos estádios. Available from: http://sportv.globo.com/site/programas/ redacaosportv/noticia/2015/02/pesquisa-violencia-e-principal-causa-queafasta-torcedores-dos-estadios.html

[33] Feddersen A, Maenning W, Borcherding M. The novelty effect of new soccer stadia: the case of germany. Int J Sport Finance 2006; 1: 174-88.

[34] Solberg H. Finding a price policy that maximises the ticket revenues at sporting events: A focus on price bundling. Eur Sport Manag Q 2001; 1(4): 300-19. [http://dx.doi.org/10.1080/16184740108721904]

[35] Howard D, Crompton J. Tactics used by sports organizations in the United States to increase ticket sales. Manag Leisure 2004; 9: 87-95. [http://dx.doi.org/10.1080/13606710410001709617]

[36] Sordi JD, Bello EC. Contribuições para o desenvolvimento dos pacotes de ingressos no futebol brasileiro: uma abordagem exploratória. Rev Intercont Gest Desport 2014; 4(2): 229-49.

[37] Levy P. Sports Administration: An examination of the competitive balance concept through European and Brazilian domestic soccer leagues comparison. M.Sc thesis, Escola de Administração de Empresas de São Paulo Fundação Getúlio Vargas: Brasil 2011.

[38] Gasparetto T, Barajas A. Análisis del balance competitivo por la diferencia de puntos acumulada (DPA). In: Proceedings of XXV Jornadas Hispanolusas. Ourense: España 2015.

[39] Itaú BBA. Análise Econômico-Financeira dos Clubes Brasileiros de Futebol Dados Financeiros de - 2014 - Parte II Alerta necessário. 2014.

[40] Ribeiro CC, Urrutia S. Scheduling the brazilian soccer tournament: solution approach and practice. Interfaces 2012; 42(3): 260-72. [http://dx.doi.org/10.1287/inte.1110.0566]

(c) Gasparetto and Barajas; Licensee Bentham Open.

This is an open access article licensed under the terms of the Creative Commons Attribution-Non-Commercial 4.0 International Public License (CC BY-NC 4.0) (https://creativecommons.org/licenses/by-nc/4.0/legalcode), which permits unrestricted, non-commercial use, distribution and reproduction in any medium, provided the work is properly cited. 